\title{
Lipoma Oral
}

\section{Oral Lipoma}

\section{Ermelindo TAVARES ${ }^{1}$}

Acta Med Port 2015 Jan-Feb;28(1):127-127

Palavras-chave: Lipoma; Neoplasias da Boca.

Keywords: Lipoma; Mouth Neoplasms.

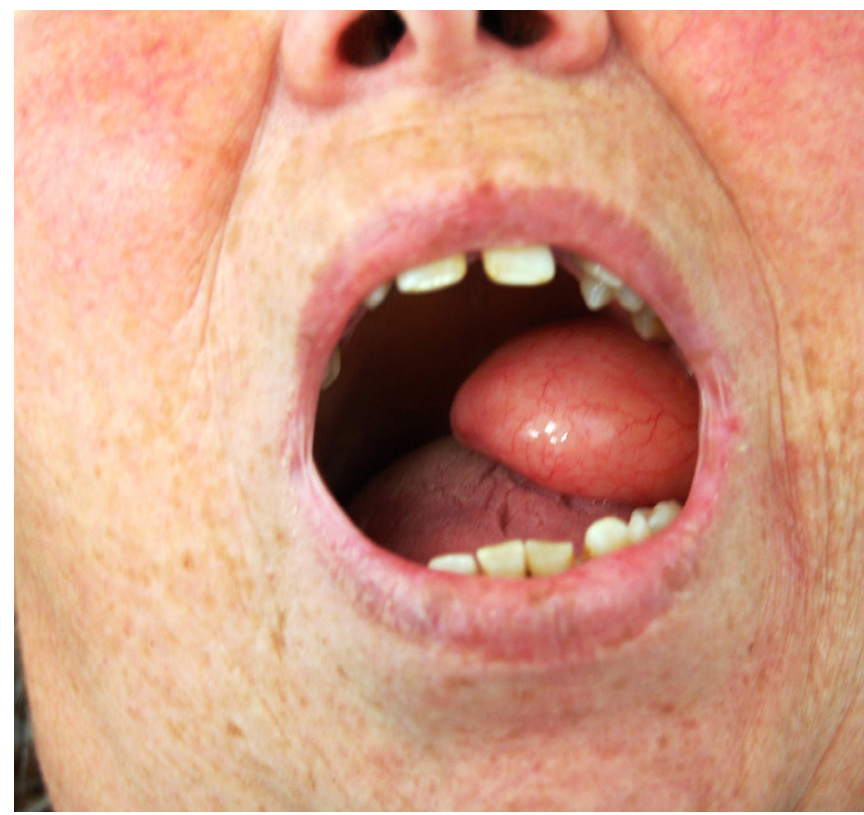

Figura 1 - Lipoma oral

Mulher de 57 anos, observada por lesão oral com 10 anos de evolução. Referia crescimento lento da mesma e dificuldades na mastigação, deglutição e fala. Ao exame objetivo apresentava massa tumoral submucosa, rosa-amarelada, ovoide, dura-elástica, indolor, móvel, com $8 \mathrm{~cm}$ de maior diâmetro, portadora de um pedículo situada na face interna da bochecha esquerda e vestíbulo (Fig. 1). Foi realizada excisão da mesma sob anestesia local (lidocaína $2 \%$ e adrenalina 1:200000), tendo o exame histológico

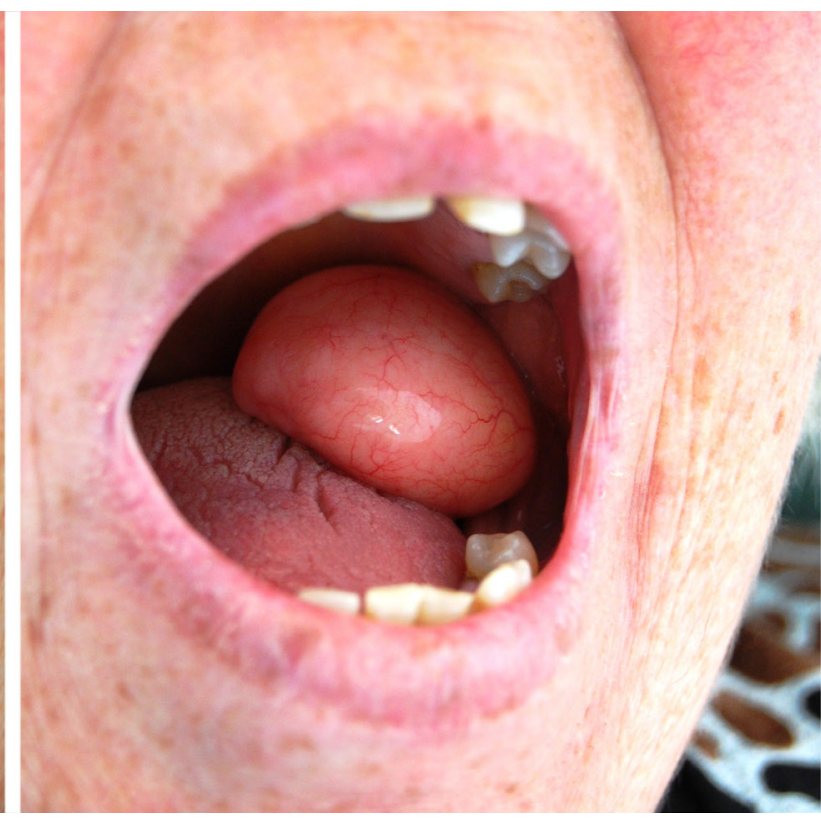

revelado lipoma, margens cirúrgicas sem tumor. Três anos depois a doente apresenta-se sem recidiva.

Lipomas são tumores mesenquimatosos frequentes que raramente ocorrem na cavidade oral (1-4\% dos casos). ${ }^{1}$ São de crescimento lento, pediculados ou sésseis. A bochecha é a localização mais comum, seguida da língua, pavimento oral, vestíbulo, palatos, lábios e gengivas. ${ }^{2} \mathrm{~A}$ excisão cirúrgica constitui o principal método de tratamento, estando associada a baixas taxas de recidivas. ${ }^{1}$

\section{REFERÊNCIAS}

1. Kaur R, Kler S, Bhullar A. Intraoral lipoma: report of 3 cases. Dent Res J. 2011;8:48-51.

2. de Visscher JG. Lipomas and fibrolipomas of the oral cavity. J Maxillofac Surg. 1982;10:177-81. 


\title{
Ermelindo TAVARES \\ Lipoma Oral
}

Acta Med Port 2015:28:127-127

Publicado pela Acta Médica Portuguesa, a Revista Científica da Ordem dos Médicos

\author{
Av. Almirante Gago Coutinho, 151 \\ 1749-084 Lisboa, Portugal. \\ Tel: +351218428 215
}

E-mail: submissao@actamedicaportuguesa.com

www.actamedicaportuguesa.com

ISSN:0870-399X | e-ISSN: 1646-0758

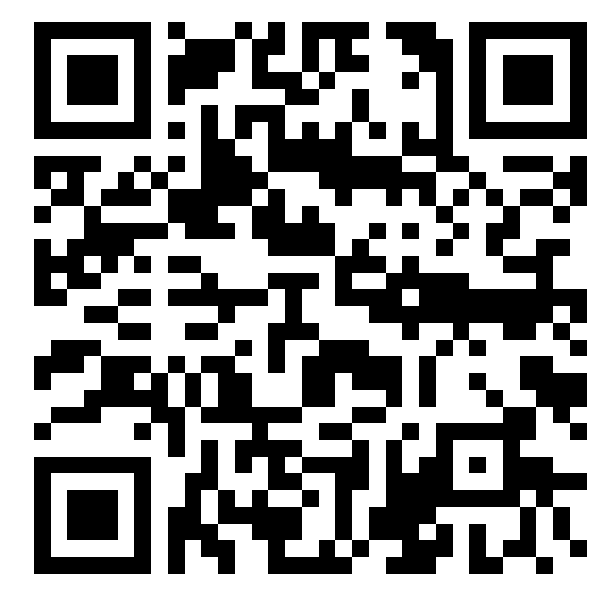

\section{ACTA MÉDICA \\ PORTUGUESA}

